\title{
Pendampingan Guru Madrasah untuk Mewujudkan Kompetensi Pedagogik Guru Matematika yang Berdaya Melalui Penguasaan Soal High Order Thinking Skills (HOTS)
}

\author{
Moh. Hafiyusholeh, Ahmad Lubab, Ahmad Hanif Asyhar, Aris Fanani, Yuniar Farida, \\ Dian C. Rini Novitasari, Nurissaidah Ulinnuha, Putroue Keumala Intan, Wika \\ Dianita Utami, Zainullah Zuhri, Ahmad Zaenal Arifin, Dian Yuliati, Abdulloh Hamid \\ UIN Sunan Ampel Surabaya \\ E-mail: hafiyusholeh@uinsby.ac.id
}

Article History:

Received: 2019-12-03

Revised: 2020-03-27

Accepted: 2020-05-31
Keywords: Community Based Research, Community Service, High Order Thinking Skill
Abstract: High Order Thinking Skills (HOTS) is the ability to connect, manipulate, and change the knowledge and experience that is owned critically and creatively in determining decisions to solve problems in new situations. To include HOTS questions in a learning process is an obstacle for Madrasah teachers, including teachers of PC. LP. Maarif NU Lamongan. This community service aimed at improving the pedagogical competence of mathematics teachers of PC. LP. Maarif NU Lamongan. Community-Based Research (CBR) was employed through workshop and training administered by the Mathematics Study Program of UIN Sunan Ampel Surabaya in designing and completing high order thinking questions followed by assistance. The results indicated that the ability of Madrasah teachers to solve HOTS questions as well as its implementation in classroom teaching and learning activities improved significantly.

\section{Pendahuluan}

Pembelajaran matematika sekolah yang dilakukan oleh guru sebagian besar lebih menekankan pada aspek pengetahuan atau pemahaman, sedangkan aspek yang lain seperti aspek aplikasi, analisis, serta aspek evaluasi kurang mendapat penekanan. Hal ini berdampak pada kurang terlatihnya siswa dalam memahami dan menyelesaikan permasalahan matematika yang bersifat non-rutin yang notabene memerlukan kemampuan berpikir tingkat tinggi.

Jika selama ini siswa lebih banyak diberikan soal-soal pada level atau tingkatan pengetahuan, pemahaman dan penerapan, yang dalam konteks taksonomi Bloom ${ }^{1}$ dikenal dengan istilah C1, C2, dan C3, maka guru dituntut untuk dapat menyusun dan juga mengajarkan soal-soal yang membutuhkan keterampilan berpikir tingkat tinggi agar

${ }^{1}$ Benyamin S Bloom, Taxonomy of Educational Objectives (The Clasification of Educational Goals) Handbook 1 Cognitive Domain. (London: Longman Group Ltd., 1979.) 
siswa memiliki kemampuan dalam menyelesaikan soal pada level C4, C5, dan C6 atau lebih dikenal dengan istilah analisis/sintesis, evaluasi dan kreasi atau mencipta. Pembelajaran matematika harusnya lebih menekankan pada pengembangan kemampuan creativity, critical thinking, collaboration dan communication ${ }^{2}$. Melalui higher order thinking skills, siswa akan mampu berargumen dengan baik, memiliki kemampuan dalam problem solving, mengkonstruksi penjelasan, memiliki memampuan melakukan hipotesis, dan juga mampu memahami hal-hal yang kompleks menjadi lebih jelas ${ }^{3}$.

High Order Thinking Skills (HOTS) merupakan kemampuan menghubungkan, memanipulasi, dan mengubah pengetahuan serta pengalaman yang dimiliki secara kritis dan kreatif dalam proses pengambilan keputusan untuk mengatasi masalah pada situasi baru4. HOTS adalah sesuatu yang tidak algoritmik ${ }^{5}$, memacu siswa untuk melakukan interpretasi, analisis atau bahkan memanipulasi berbagai informasi sehingga tidak terkesan monoton. HOTS merupakan kemampuan berpikir tingkat tinggi yang memuat kemampuan untuk berpikir kritis, logis, reflektif, metakognitif, dan kreatif. ${ }^{6}$ Melibatkan aktivitas mental dalam mengeksplorasi pengalaman yang kompleks reflektif dan kreatif yang dilakukan secara sadar dengan tujuan memperoleh pengetahuan yang meliputi analisis sintesis dan evaluatif.7 Oleh karenanya untuk keperluan ini, dibutuhkan proses yang kontinu dan konsisten dalam melatih dan membiasakan para siswa, dimulai sejak awal kegiatan pembelajaran sampai dengan proses refleksi dan evaluasi. Guru dalam konteks ini harus mampu memfasilitasi siswa menjadi pribadi-pribadi pemikir dan pemecah masalah yang baik. ${ }^{8}$ Karena guru masuk dalam wilayah pekerjaan profesi, maka kompetensi guru yang unggul sangatlah dibutuhkan dalam proses belajar mengajar, termasuk kompetensi guru dalam membelajarakan soal-soal non-rutin atau soal HOTS.

2 Rafiq Badjeber, Jayanti Putri Purwaningrum, "Pengembangan Higher Order Thinking Skills dalam Pembelajaran Matematika di SMP”. Guru Tua : Jurnal Pendidikan dan Pembelajaran 1, No. 1, (2018): 36.

3 Widodo, T \& Kadarwati, S. "High Order Thinking Berbasis Pemecahan Masalah Untuk Meningkatkan Hasil Belajar Berorientasi Pembentukan Karakter Siswa". Cakrawala Pendidikan (2013) 32(1), 161-171.

${ }^{4}$ Husna Nur Dinni, "HOTS (High Order Thinking Skills) dan Kaitannya dengan Kemampuan Literasi Matematika". PRISMA 1 Prosiding Seminar Matematika (2018): 170. diakses pada tanggal, 6 Nopember 2019 melalui ttps://journal.unnes.ac.id/sju/index.php/prisma/.

5 Triana Jamilatus Syarifah, Budi Usodo, Riyadi., "Higher Order Thinking (Hot) Problems To Develop Critical Thinking Ability And Student Self Efficacy In Learning Mathematics Primary Schools", Social, Humanities, and Education Studies (SHEs): Conference Series 1 (2018): 917-925. https://jurnal.uns.ac.id/shes . hal. 919.

${ }_{6}^{6}$ Budiman, dkk. Pengembangan Instrumen Asesmen Higher Order Thinking Skill (HOTS) Pada Mata Pelajaran Matematika SMP Kelas VII Semester 1. Jurnal Riset Pendidikan Matematika, Vol. 1 No. 2. 2014. hal 3

7 Dian Novianti. “Analisis Kemampuan Berpikir Tingkat Tinggi Siswa Dengan Gaya Belajar Tipe Investigatif dalam Pemecahan Masalah Matematika Kelas VII Di SMPN 10 Kota Jambi”. Jurnal Mahasiswa. (April 2014): 1 - 10. Diakses pada 15 November 2019. http://e-campus.fkip.unja.ac.id/eskripsi/data/ pdf/jurnal_mhs/artikel/RRA1C209035.pdf.. hal 4.

${ }^{8}$ Rafiq Badjeber, Op.Cit, hal. 36. 
Permasalahannya kemudian, penerapan pembelajaran HOTS bukan sesuatu yang mudah diterapkan dan dilaksanakan oleh guru terutama guru Madrasah yang berada di bawah koordinasi PC. LP. Maarif NU Lamongan. Berdasarkan hasil pre-test kemampuan guru dalam merancang dan menyelesaikan soal HOTS yang dilakukan terhadap 33 guru ditemukan sebanyak $18.2 \%$ atau 6 guru yang memenuhi target kemampuan menyelesaikan soal HOTS, sedangkan yang belum memenuhi target sebesar $81 \%$ atau sebanyak 27 guru. Jika dirata-rata, total kemampuan guru masih berada pada level cukup dengan rata-rata skor 67.

Melalui wawancara diperoleh simpulan bahwa guru mengalami kesulitan dalam membelajarkan soal HOTS di sekolah karena tuntutan administrasi guru yang banyak menyita waktu dan tenaga sehingga pengembangan pembelajaran menjadi terabaikan. Hal ini selaras dengan hasil penelitian yang dilakukan oleh Nanik Ulfa, Aan Fardani Ubaidillah, \& Isna Nurul Inayati ${ }^{9}$. Selain itu observasi yang dilakukan oleh peneliti, masih terdapat guru yang mengajar matematika di madrasah akan tetapi latar belakang keilmuannya tidak linier yaitu lulusan Pendidikan Agama Islam. Padahal guru dituntut untuk memiliki kompetensi yang unggul dibidangnya, baik itu kompetensi pedagogik, kepribadian, sosial maupun kompetensi professional. Terdapat juga guru yang hanya berorientasi pada penyampaian materi dengan minim kreatifitas untuk memberikan tantangan lebih kepada siswa. Hal ini pada akhirnya dapat berdampak pada sebagian besar siswa Madrasah merasa kurang confident dalam bersaing dengan sekolah-sekolah umum terutama dalam ajang kompetisi Olimpiade Matematika atau sejenis. Walaupun ada juga guru-guru madrasah yang melakukan pembelajaran secara maksimal agar kegiatan pembelajaran menarik, kualitas soal matematika juga sudah dikondisikan untuk soal-soal non-rutin, akan tetapi respon siswa yang kurang baik dan relatif pasif menjadikan hasil pembelajaran kurang optimal.

Dari sekian banyak guru matematika di madrasah, masih banyak diantara mereka yang melakukan aktifitas pembelajaran yaitu hanya sekedar memenuhi target ketuntasan materi, sehingga soal-soal non-rutin atau soal yang mengandung unsur high order thinking menjadi terabaikan yang berdampak pula terhadap kesuksesan siswa dalam menghadapi ujian nasional. Selain itu, guru-guru madrasah di bawah PC. LP. Maarif NU belum banyak melakukan inovasi pembelajaran, baik dalam pemilihan metode, media dan sarana pendukung lainya untuk meningkatkan mutu pembelajaran dan mengatasi permasalahan yang sering muncul dalam proses pembelajaran, terutama dalam konteks penerapan soal berbasis High Order Thinking Skills (HOTS).

Sebagai contoh kasus ujian nasional pada tahun 2018 yang menyertakan soal-soal HOTS. Nilai UN bidang matematika cenderung turun untuk setiap tahunnya ${ }^{10}$. Banyak

9 Nanik Ulfa, dkk. Pendampingan Guru Melalui Capacity Building dalam Rangka Optimalisasi Implementasi Penilaian Otentik Kurikulum 2013 (K-13) di MINU Curungrejo Kepanjen Malang. Engagement: Jurnal Pengabdian Kepada Masyarakat, (2019), 3(1), 32-43.

10 Kemdikbud. Konferensi Pers UN 2018 Jenjang SMP. (Online), (https://kemdikbud. 
siswa yang mengeluhkan adanya soal-soal tersebut, karena selama di sekolah, mereka tidak diajarkan atau tidak banyak diajarkan dan disiapkan untuk menyelesaikan soal-soal HOTS. Tidak diajarkannya siswa di dalam melakukan analisis soal-soal HOTS tersebut bisa jadi karena guru yang bersangkutan tidak menguasai soal-soal dengan tipe yang dimaksud. Oleh karenanya penguasaan soal HOTS sangat diperlukan untuk meningkatkan kompetensi pedagogis guru. Kemampuan ini harus terus diasah sebagaimana yang dilakukan oleh PC. LP. Ma'arif NU Kab. Lamongan baik berupa pelatihan guru ${ }^{11}$, maupun pendampingan dan supervisi terhadap guru-guru di bawah naungan LP. Ma'arif.

Beberapa dampak yang ditimbulkan dari penguasaan soal HOTS antara lain: Siswa akan belajar lebih mendalam dan memahami konsep dengan baik ${ }^{12}$. Melalui HOTS, siswa secara jelas akan dapat menemukan ide atau gagasan, mampu memecahkan masalah, berargumen dengan baik, mengkonstruksi penjelasan, berhipotesis dan juga memahami hal-hal kompleks menjadi lebih jelas. Melalui pendekatan HOTS siswa dapat dipicu untuk aktif berpikir belajar, khususnya dalam pemecahan masalah. Pengembangan literasi matematika berbasis keterampilan berpikir tingkat tinggi (higher order thinking) memungkinkan siswa untuk bertanya, melakukan identifikasi, dan terlibat dalam diskusi13. Oleh karenanya, kemampuan siswa dalam memahami dan menyelesaikan soalsoal yang berbasis HOTS dapat ditingkatkan dengan memberikan bahan ajar yang sesuai14. Tidak hanya pada siswa, guru juga sangat berpeluang menghadapi tantangan dalam menafsirkan keterampilan berpikir dalam taksonomi Bloom serta menyusun instrumen penilaian dalam bentuk tes untuk berpikir tingkat tinggi ${ }^{15}$.

Dengan memperhatikan beberapa kondisi tersebut, maka perlu ada suatu kajian dan penelitian terhadap treatmen yang dapat dilakukan untuk meningkatkan kemampuan guru-guru Madrasah di bawah naungan PC. LP. Maarif NU Lamongan dalam bentuk pengabdian dan pendampingan. Pengabdian ini memiliki nilai urgensi yang sangat besar untuk pengembangan kelembagaan Perguruan Tinggi Islam di Indonesia maupun untuk lembaga di bawah Kementerian Agama. Sebagai salah satu Prodi di lingkungan UIN Sunan Ampel Surabaya yang harus melaksanakan Tridharma Perguruan

go.id/main/files/do wnload/9c7fdf36a39328d), diakses 1 Oktober 2018

11 https://www.timesjatim.com/read/45204/20180909/222524/lp-maarif-nu-kabupaten-lamo ngan-terus-asah-kualitas-guru/

12 Widodo, T. dan Kadarwati, S. "High Order Thinking Berbasis Pemecahan Masalah Untuk Meningkatkan Hasil Belajar Berorientasi Pembentukan Karakter Siswa". Cakrawala Pendidikan (2013) 32(1), 161-171.

13 Martalyna, dkk. Integrasi Keterampilan Higher Order Thinking dalam Perspektif Literasi Matematika. PRISMA, Prosiding Seminar Nasional Matematika. Vol 1 (2018): 1, 345-363. diakses pada 03 Desember 2019. https://journal.unnes.ac.id/sju/index.php/prisma/article/view/19616

14 Musfiqi, S. dan Jailani, "Pengembangan Bahan Ajar Matematika yang Berorientasi pada Karakter dan Higher Order Thinking Skill (HOTS)". PYTHAGORAS: Jurnal Pendidikan Matematika (Juni 2014) 9. No. 1,: 45-59.

15 Thompson. “Mathematics Teachers Interpretation of Higher-Order Thinking in Bloom's Taxonomy”. International Electronic Journal of Mathematics Education, (2008) 3, No. 2. Hal. 32. 
Tinggi, maka Prodi Matematika merasa terpanggil untuk menjadi bagian dari system yang saling melengkapi dalam memajukan pendidikan di Madrasah. Wujud kemajuan yang dimaksud adalah terwujudnya sumber daya manusia (Guru) Matematika yang unggul, berkualitas, dan berdaya saing.

Pengabdian ini diharapkan bisa menjadi stimulasi bagi pihak pengambil kebijakan untuk mengembangkan model pembelajaran dengan menekankan pada penguasaan soal-soal non-rutin yang membutuhkan high order thinking dalam penyelesaiannya. Tidak menutup kemungkinan pula, hasil pengabdian ini menjadi 'blue print' untuk dijadikan benchmarking dan diadopsi oleh semua PTAIN yang berada diseluruh daerah, untuk ikut bertanggungjawab dalam melahirkan dan membina guru-guru madrasah yang mempunyai profesionalitas secara pedagogis, maupun sosial

Disinilah program pengabdian masyarakat untuk meningkatkan kompetensi pedagogis dan pengusaan soal-soal berbasis HOTS perlu dilaksanakan dalam rangka untuk menjembatani sekaligus sebagai solusi atas kemampuan guru madrasah dan tuntutan akan standar kompetensi lulusan secara nasional. Dengan adanya kesadaran untuk berubah, maka sistem pembelajaran yang lebih inovatif berbasis High Order Thinking Skills (HOTS) akan terwujud.

\section{Metode}

Metode yang digunakan dalam untuk mencapai kondisi yang diharapkan adalah dengan CBR (Community-Based Research) karena pendekatan ini bisa implementasikan dalam keterpaduan Tridharma baik melalui penelitian, pendidikan, dan pengabdian ${ }^{16}$. Metode tersebut memperhatikan identifikasi masalah dan upaya preventif bagi masyarakat, identifikasi proritas dukungan, pengembangan sistem dan pembangunan sosial, identifikasi pengembangan program yang fokus pada masyarakat, dan menjawab kebutuhan masyarakat ${ }^{17}$.

Pihak yang terlibat adalah PC. LP. Maarif NU Kab. Lamongan beserta guru-guru SMA/MA yang berada di bawah naungan lembaga tersebut. Hal ini karena PC. LP. Maarif mempunyai organ untuk dapat ikut serta dalam memberikan dukungan dan peran serta secara aktif dalam proses pemberdayaan untuk menghasilkan sesuatu yang bermanfaat bagi guru dan lembaga. Tempat dilaksanakan kegiatan adalah Aula PC. LP. Maarif NU Kab. Lamongan dan Yayasan Pendidikan Al-Khoiriyah Mantup sebagai tempat pendampingan lanjutan. Waktu pendampingan adalah tiga bulan terhitung sejak awal bulan Agustus sampai dengan Oktober 2019.

16 Tim Penyusun Panduan CBR UIN Sunan Ampel Surabaya, Community Based Research: Sebuah Pengantar (Surabaya: SILE/LLD, 2015). Hal. 1

${ }^{17}$ Chusnul Chotimah, "Pengembangan Sekolah Berbasis Go Green dan Waste Manajemen untuk Mewujudkan Green School di SDI Miftahul Huda Plosokandang Kabupaten Tulungagung". Engagement: Jurnal Pengabdian Kepada Masyarakat. Volume 3, Number 2, November 2019. hal.147 
Adapun tahapan dalam penelitian ini mengacu pada tahapan $\mathrm{CBR}^{18}$, yaitu Meletakkan Dasar (Laying Foundation), Perencanaan Penelitian (Research Planning), Pengumpulan dan Analisis Data (Gathering and Analysis Information), Tindak Lanjut Penemuan (Acting on Finding):19

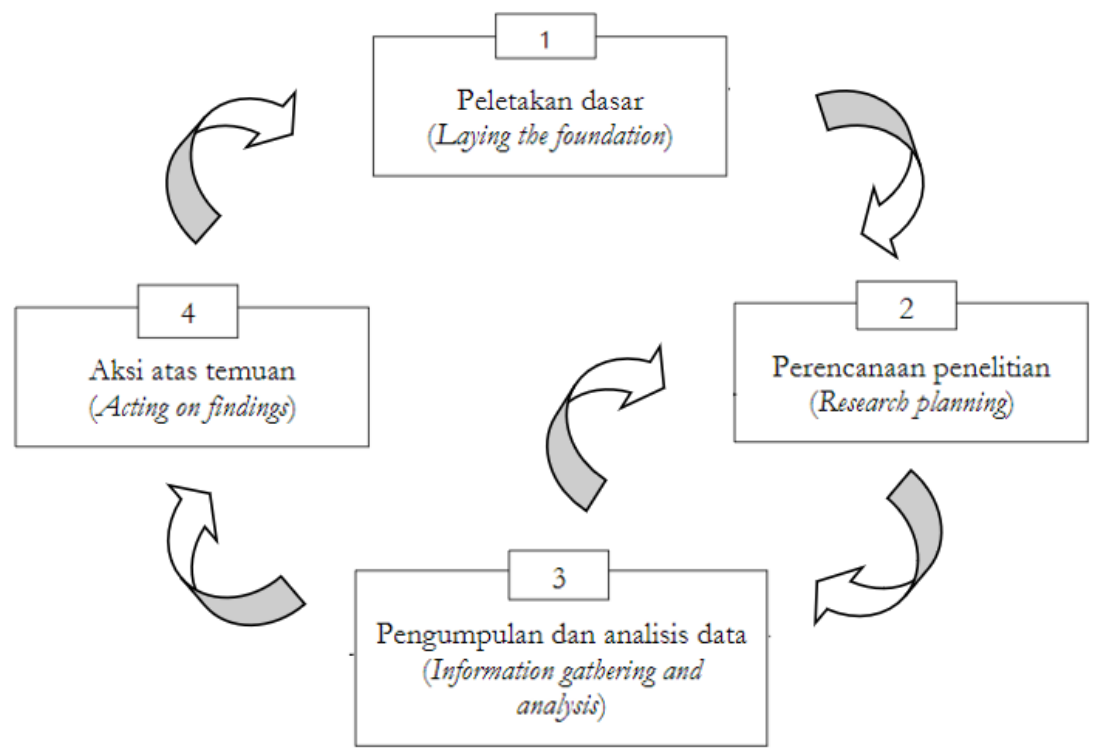

Gambar 1. Tahapan dalam CBR

Berdasar tahapan CBR sebagaimana Gambar 1, maka kegiatan pengabdian/penelitian ini didesain sebagai berikut:

1. Meletakkan Dasar (Laying Foundation). Pada tahap ini dilakukan dengan melibatkan PC. LP. Maarif NU Kab. Lamongan sebagai mitra dampingan, kelompok kerja madrasah, kepala sekolah, dosen dan tutor bimbingan belajar. Kegiatan yang dilakukan adalah Focus Group Discussion (FGD) dalam rangka untuk memetakan subjek dampingan, urgensi dilakukannya dampingan, tujuan dilakukan pendampingan atau penelitian, identifikasi masalah dan kebutuhan dari subjek dampingan, menentukan target akhir dari pendampingan. Oleh karenanya subjek dampingan disamping mengikuti kegiatan pelatihan juga berperan dalam mengembangkan serta mengimplementasikan konsep dasar pelatihan terhadap siswa di madrasahnya masing-masing.

2. Perencanaan Penelitian (Research Planning). Melalui komunikasi dengan berbagai stakeholder, maka disusun rencana pendampingan yang dimulai dari identifikasi

18 Mohammad Hanafi, dkk., "Community Based Research. Panduan Merancang dan Melaksanakan Penelitian Bersama Komunitas”, Surabaya: LP2M. Hal. 47 - 52.

19 Muhid, dkk.. Perubahan Perilaku Open Defecation Free (ODF) melalui Program Sanitasi Total Berbasis Masyarakat (STBM) di Desa BabadKecamatan Kedungadem Kabupaten Bojonegoro. Engagement: Jurnal Pengabdian Kepada Masyarakat, (2018), 2(1), 99-119. 
masalah, pemberian pelatihan berupa workshop, pendampingan pasca workshop sampai dengan evaluasi keberhasilan program melalui pemberian tes kemampuan menyusun dan mengerjakan soal HOTS.

3. Pengumpulan dan Analisis Data (Gathering and Analysis Information). Pada tahap ini dilakukan pengumpulan data, pengorganisasian data, analisis data sampai pada penyimpulan dari hasil analisis data yang dilakukan. Kegiatan ini dilakukan dengan melibatkan mitra dampingan. Beberapa metode yang dilakukan adalah dengan tes, wawancara, kuisioner, dan dokumentasi.

4. Tindak Lanjut Penemuan (Acting on Finding). Setelah dilakukan analisis data, peneliti bersama dengan mitra atau komunitas dampingan melakukan rencana tindaklanjut untuk menjamin bahwa kegiatan yang telah dilakukan benar-benar membawa perubahan ke arah yang lebih baik.

\section{Hasil}

PC. LP Ma'arif NU Kab. Lamongan merupakan lembaga departemenisasi NU di bidang pendidikan formal yang memiliki fungsi dan peran untuk melaksanakan berbagai kebijakan di bidang pendidikan formal NU dari tingkat dasar sampai perguruan tinggi baik yang berada di bawah binaan Kemendikbud maupun di bawah Kementerian Agama yang berada di level Kabupaten atau Kota. PC. LP. Maarif NU Kab. Lamongan menaungi beberapa lembaga setingkat SMA/MA diantaranya SMA Islam Terpadu Al Azhar Brondong, SMA Mazra'atul Ulum, SMA NU Centini, MA Ma'arif 19 Hasyim Asyari, MA Darul Ulum, MA Ma'arif 9 Mambaul Ulum, dan lain sebagainya.

Melalui Focus Group Discussion (FGD) dengan melibatkan mitra dampingan, dosen ataupun tutor, dan kepala madrasah dilakukan identifikasi masalah serta aksi penyelesaian masalah. Identifikasi masalah meliputi kondisi di lapangan mengenai kemampuan Guru dalam mengkonstruksi soal HOTS maupun menyelesaikan soal HOTS, permasalahan-permasalahan yang dihadapi oleh guru Matematika dalam implementasi pembelajaran berbasis soal HOTS.

Berdasarkan hasil identifikasi bersama diperoleh suatu simpulan yaitu: 1) Tenaga pendidik atau guru Madrasah dalam melakukan proses pembelajaran sehari-hari belum banyak menerapkan keterampilan soal-soal nonrutine diantaranya adalah soal bertipe High Order Thinking. 2) Sebagian besar siswa Madrasah merasa kurang confident dalam bersaing dengan madrasah atau sekolah-sekolah umum terutama dalam ajang kompetisi Olimpiade Matematika atau sejenis. 3) Madrasah yang berada di bawah naungan PC. LP. Maarif NU Kab. Lamongan selama ini belum banyak melakukan inovasi pembelajaran, baik dalam pemilihan metode, media dan sarana pendukung lainya untuk meningkatkan mutu pembelajaran dan mengatasi permasalahan yang sering muncul dalam proses pembelajaran, terutama dalam konteks penerapan soal berbasis Higher Order Thinking Skills. 
Berdasarkan kondisi obyektif Madrasah di lingkungan PC. LP. Maarif NU Kab. Lamongan, maka terdapat beberapa kebutuhan yang diidentifikasi, antara lain: Guru membutuhkan pelatihan pembuatan soal HOTS, Guru memerlukan pelatihan strategi dalam menyelesaikan soal HOTS, Guru memerlukan pendampingan dan referensi yang dapat digunakan sebagai acuan dalam membelajarkan soal HOTS. Oleh karena itu, dirumuskanlah pelatihan dan pendampingan berupa Workshop untuk Guru Matematika melalui penguasaan soal HOTS dengan target yang diharapkan adalah: 1) Munculnya kesadaran Guru dan peserta didik (siswa) Madrasah tentang problem yang dihadapi dan munculnya kemauan untuk melakukan perubahan. 2) Melalui pendampingan berbasis partisipatif ini, diharapkan para pendidik (guru) mampu melakukan inovasi dalam proses pembelajaran. 3) Terbentuk kelompok (core group) Guru Madrasah yang siap untuk melakukan pengembangan sistem pembelajaran yang mengintegrasikan penguasaan soal-soal HOTS dengan pembelajaran setiap harinya. 4) Munculnya inovasiinovasi dalam proses pembelajaran, baik dalam pemilihan metode, media dan sarana pendukung lainya untuk meningkatkan mutu pembelajaran dan mengatasi permasalahan yang sering muncul dalam proses pembelajaran.

Pemberian treatmen berupa workshop ataupun pelatihan menjadi sarana yang sangat efektif dalam meningkatkan kemampuan dan kualitas pembelajaran. Forum ilmiah seperti pendidikan dan pelatihan,workshop, atau kegiatan-kegiatan yang dilakukan di dalam KKG/MGMP menjadi sarana yang sangat strategis untuk mewujudkan kemampuan dan kualitas pembelajaran yang lebih berdaya. Pada kegiatan-kegiatan tersebut, disamping guru mendapatkan wawasan baru dari para ahli/pakar, guru juga dapat melakukan diskusi, sekaligus praktek menerapkan pembelajaran dan penilaian HOTS 20 .

Berdasarkan analisis terhadap kebutuhan tersebut, maka pada tahap implementasi, tim melakukan beberapa persiapan pelaksanaan yaitu dengan melakukan koordinasi internal di masing-masing kepanitiaan diantaranya materi workshop yang meliputi pembuatan soal untuk pre-test dan pos-test, daftar hadir, narasumber, dan instruen evaluasi sebagai feedback kegiatan, serta akomodasi kegiatan. Beberapa pemateri yang dilibatkan antara lain: Dian Yuliati, M.Si (Praktisi Bimbel ), Satria Stansa, M.Si (Pembina Olimpiade Nasional), Zaenal Arifin, M.Si (Dosen Unirow Tuban), Zainullah Zuhri, M.Si (Praktisi LBB Smart Student Partner), Ahmad Hanif Asyhar, M.Si (Dosen Uinsa, Pembina Olimpiade dan Praktisi LBB), dan Putroue Keumala Intan, M.Si (Dosen Uinsa). Adapun materi yang disampaikan terdiri dari Materi I Pengenalan Soal HOTs, Materi II Strategi Penyusunan Soal, Materi III Teknik Penyelesaian Soal, Materi IV Strategi Penyusunan Soal HOTS dan Penyelesaianya, Materi V Review Soal UNAS dan Simulasi

\footnotetext{
${ }^{20}$ Idris Apandi, "Pembelajaran dan Penilaian HOTS”, Kompasiana, diakses pada tanggal 7 Nopember 2019 melalui laman: https://www.kompasiana.com/idrisapandi/58d8e31e8d7a61cc217f38c2/ pembelajaran-dan-penilaian-hots
} 
Pembuatan Soal, Materi VI Diskusi Kelompok Pembuatan Soal HOTS Berbasis Kompetensi Dasar.

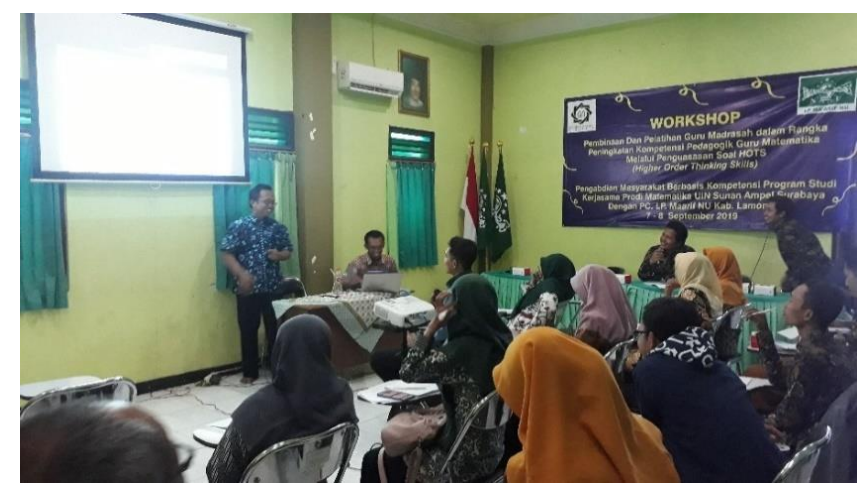

Gambar 2. Workshop Penguasaan Soal HOTS

Sebagai bahan evaluasi pelaksanaan kegiatan, peneliti memberikan angket penilaian dalam format google form dengan 4 cluster respon jawaban yaitu tidak baik, baik, cukup baik, baik, dan sangat baik.. Berdasarkan angket yang diberikan, diperoleh hasil respon sebagai berikut: 1) Kesesuaian pelatihan atau pendampingan terhadap pekerjaan sebanyak 79\% menjawab sangat baik sedangkan 21\% memberikan respon baik. 2) Penguasaan materi dinilai $74 \%$ sangat baik sedangkan $26 \%$ sisanya menjawab baik. 3) Begitu juga dengan penilaian terhadap kualitas pendampingan dan pelatihan, responden menilai $82 \%$ sangat baik sedangkan 18\% sisanya baik, 4) Terhadap tanggapan metode yang diberikan, sebanyak 91\% menilai sangat baik sedangkan 9\% menilai baik, 5) Secara keseluruhan, respon peserta dampingan memberikan nilai sangat baik terhadap keseluruhan pelatihan/pendampingan yaitu sebesar 85\%.

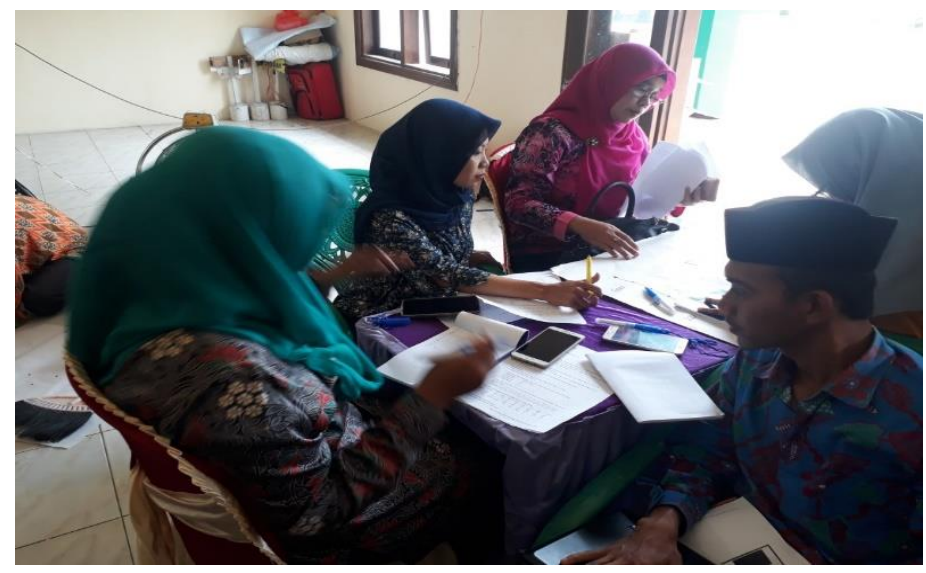

Gambar 3. Pendampingan Guru Madrasah

Selain kuisioner, beberapa tanggapan hasil wawancara yang telah dilakukan menunjukkan bahwa semua peserta merasa terbantu dengan adanya kegiatan ini. Jika selama ini mereka hanya memberikan soal-soal rutin sebagai akibat keraguan mereka terhadap kondisi siswa, maka mereka selepas pelatihan akan mencoba melakukan 
perubahan terhadap proses dan cara pembelajaran. Mereka akan menerapkan pembuatan soal HOTS sebagaimana materi yang telah diajarkan, Membenahi cara membuat soal, berlatih membuat soal HOTS dan melatih siswa mengerjakan soal hots, Mengubah pola soal yang biasanya hanya mengacu pada contoh di buku paket, menjadi bentuk yang dinarasikan dan disusun sendiri dengan memperhatikan kaidah penyusunan soal yang memiliki level sintesis, analisis, dan kreasi. Selain itu, mereka juga berkomiteman untuk enganalisis soal-soal yang sudah ada, yang notabene masuk dalam kategori Lower Order Thinking Skills untuk direkonstruksi menjadi soal HOTS, Melakukan sharing materi dengan sesama guru.

Sebagai tahapan akhir pemberian workshop dan pendampingan Guru Madrasah dalam Rangka Peningkatan Kompetensi Pedagogik Guru Matematika Melalui Penguasaan Soal HOTS, maka dilakukan test. Uji coba dilakukan untuk mengetahui tingkat keberhasilan program pelatihan dan pendampingan. Tes dilakukan terhadap 33 guru pada saat sebelum diberikan workshop dan pendampingan. Hasil dari pre-test menunjukkan nilai maksimum pencapaian adalah 85 sedangkan nilai minimum sebesar 50. Mean, median dan modus masing-masing sebesar 67.91, 68.11, dan 68.7 dengan simpangan baku sebesar 8.29 .

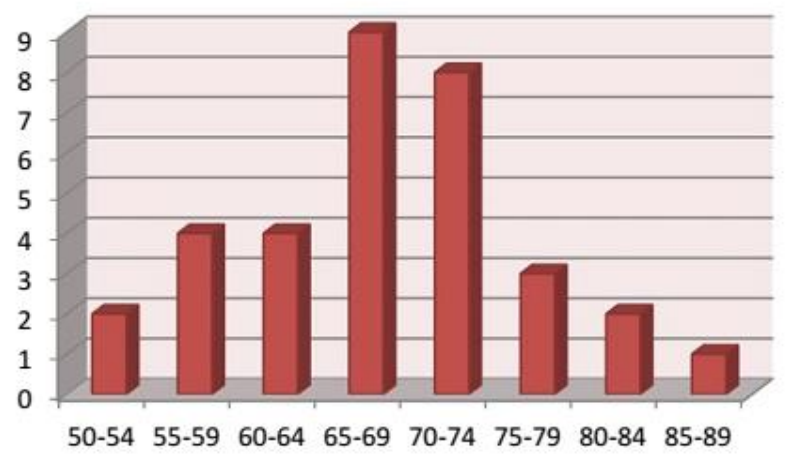

Gambar 4. Histogram Pre-Test Kemampuan Penyelsaian Soal HOTS

Berdasarkan data tersebut, diketahui Guru yang memenuhi target ketercapaian sebanyak $18.2 \%$ atau 6 guru. Sedangkan yang belum memenuhi target sebesar $81 \%$ atau sebanyak 27 guru. Dengan demikian dapat ditarik suatu simpulan bahwa kemampuan guru dalam menyeelsaikan soal HOTs masih belum memuaskan. Hasil pencapaian pretest dapat disajikan dalam bentuk diagram lingkaran sebagai berikut.

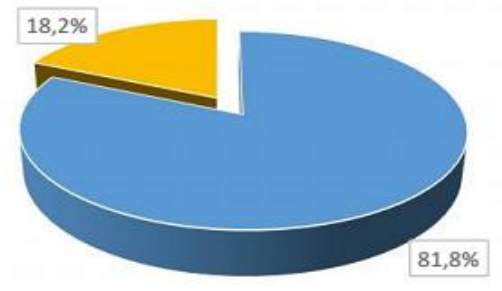

Gambar 5. Diagram Lingkaran Pre-Test Kemampuan Penyelesaian Soal HOTS 
Selanjutnya setelah dilakukan treatment berupa pemberian workshop dan pendampingan terhadap guru-guru yang berada di lingkungan PC. LP. Maarif NU Kab. Lamongan, diperoleh nilai rata-rata 86,24 untuk hasil post-test, nilai tengah sebesar 86,09 , nilai yang sering muncul atau modus sebesar 84,08 dan simpangan baku 4.28. Jika digambarkan dalam bentuk histogram, maka diperoleh hasil

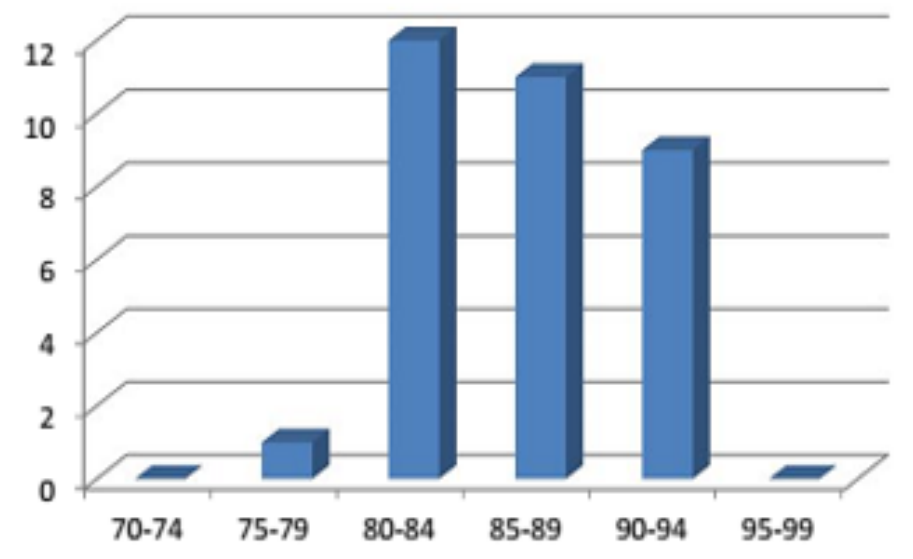

Gambar 6. Histogram Post-Test Kemampuan Penyelesaian Soal HOTS

Berdasarkan pengolahan data tersebut, maka dapat dibuat suatu simpulan bahwa target pencapaian Guru dalam memahamai dan mengerjakan soal high order thinking sebesar $100 \%$ yang melampaui target nilai $>75$. Tabel perbandingan nilai penguasaan guru saat sebelum diberikan perlakukan dan saat setelah diberikan perlakukan berupa pelatihan dan pendampingan dapat disajikan dalam tabel berikut.

Tabel 1. Statistik Hasil Pre-Test dan Post-Test

\begin{tabular}{lcc}
\hline \multicolumn{1}{c}{ Statistik } & Pretest & Post-test \\
\hline Nilai Minimum & 50 & 77 \\
\hline Nilai Maksimum & 85 & 90 \\
\hline Rata-rata & 67,91 & 86,24 \\
\hline Simpangan baku & 8,29 & 4,28 \\
\hline Range & 35 & 13 \\
\hline Median & 68,11 & 86,09 \\
\hline Modus & 68,7 & 84,08 \\
\hline
\end{tabular}

Berdasarkan Tabel 1 tersebut, rata-rata penguasaan guru dalam menyelesaikan soal High Order Thinking sebelum dan sesudah diberikan treatment berupa pelatihan dan pendampingan mengalami peningkatan sebesar 18.33 point dengan simpangan baku post-tes lebih kecil dibandingkan dengan saat sebelum diberikan perlakukan. Hal ini mengindikasikan sebaran data lebih memusat di titik pusat dibandingkan saat sebelum 
diberikan perlakuan.

Kegiatan selanjutnya adalah melakukan pendampingan. Kegiatan pendampingan dimulai dengan meneken Perjanjian Kerjasama dengan PC. LP. Maarif NU Kab. Lamongan sebagai mitra dampingan untuk terus berkolaborasi dan bersinergi dalam mewujudkan Pendidikan yang berkualitas khususnya di Madrasah. Beberapa hal yang akan dilaksanakan untuk memperkuat kualitas madrasah adalah 1) Perlu dibuat pelatihan lanjutan berupa workshop pembina olimpiade matematika, 2) PC. LP. Maarif NU Kab. Lamongan akan memfasilitasi pertemuan rutinan guru-guru matematika yang sudah tergabung dalam Perhimpunan Guru Matematika Madrasah NU dengan melibatkan Prodi Matematika UIN Sunan Ampel sebagai kosultan, 3) Perlu dibentuk kelas olimpiade di masing-masing Madrasah yang dinilai potensial sebagai Madrasah Model sebagai cikal bakal peningkatan prestasi siswa madrasah di ajang kompetisi nasional.

Agar proses pendampingan berjalan dengan optimal, maka dibuat WhatsApp Group (WAG) yang melibatkan semua peserta. Tujuannya adalah memudahkan koordinasi sekaligus memfasilitasi tanya jawab seputar matematika terutama soal-soal non-rutine dan pembuatan soal HOTS. Langkah lanjutan adalah membentuk struktur kepengurusan Perhimpuan Guru Matematika Madrasah NU, dengan diketuai oleh Ririn Indayani, S.Pd. dari MA Ma'arif 19 Hasyim Asyari. Sedangkan Rukiyati, S.Si dari MA Matholi'ul Anwar didaulat sebagai Sekretaris dan Bendahara dijabat oleh Enawati, S.Pd dari MA Ma'arif 9 Mambaul Ulum. Anggota perhimpunan diambilkan dari semua peserta Workshop.

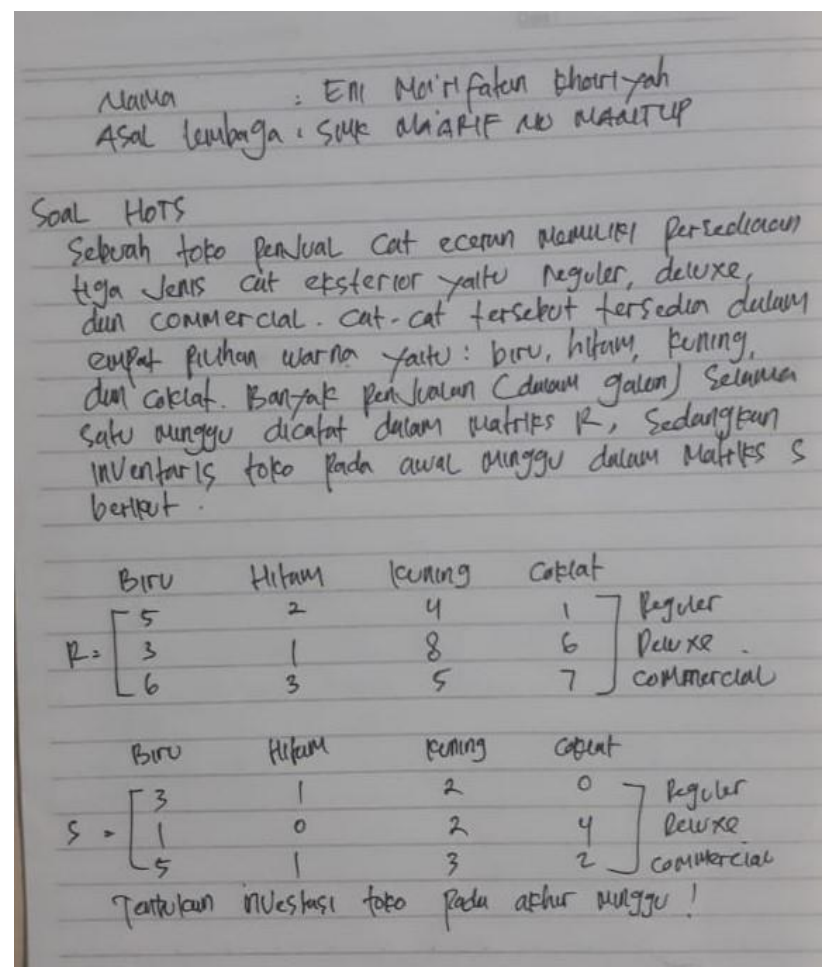

Gambar 7. Contoh Variasi Soal HOTS Peserta Dampingan 
Pendampingan juga dilakukan dengan mendatangi sekolah/Madrasah untuk melihat sejauh mana perkembangan implementasi pembuatan soal HOTS yang dilakukan oleh guru-guru pasca diberikan pelatihan.

\section{Diskusi}

Berdasarkan hasil identifikasi awal pada guru-guru diperoleh suatu kenyataan bahwa tenaga pendidik atau guru Madrasah dalam melakukan proses pembelajaran belum banyak menerapkan keterampilan soal-soal nonrutine berbasis high order thinking skills. Kondisi tersebut tentu berpengaruh terhadap siswa. Bisa jadi siswa mengalami kondisi kurang teliti dalam proses pengerjaan soal, ketidaklengkapan dalam membaca soal yang berdampak pada kekeliruan terhadap penyelesaian soal, kurangnya pemahaman siswa terhadap soal yang diberikan sebagaimana hasil penelitian Gais dan Afriansyah (2017) ${ }^{21}$ yang ujung-ujungnya adalah prestasi belajar siswa menjadi tidak maksimal. Salah satu solusi yang diberikan adalah pemberian treatment berupa workshop ataupun pelatihan. Guru diberikan workshop dengan tema "Pembinaan dan Pelatihan Guru Madrasah dalam Rangka Peningkatan Kompetensi Pedagogik Guru Matematika Melalui Penguasaan Soal HOTS (Higher Order Thinking Skills)". Melalui pelatihan ini diharapkan muncul suatu kesadaran guru untuk melakukan inovasi dalam proses pembelajaran, melakukan pengembangan sistem pembelajaran yang mengintegrasikan penguasaan soal-soal HOTS dengan pembelajaran setiap harinya. Selain itu, pelatihan berupa pengembangan soal HOTS sebagaimana yang dinyatakan oleh Wicaksono dan Jumanto $(2019)^{22}$ dibutuhkan guru dalam pengembangan pembelajaran abad 21 dan menunjang era revolusi industri 4.0.

Efektifitas pelatihan atau workshop juga dapat dilihat pada penelitian yang dilakukan oleh Hartini dan Martin²3; Wicaksono dan Jumanto ${ }^{24}$; Rintayanti, Istiyati, dan Syawaludin ${ }^{25}$. Pelatihan atau workshop tersebut dipandang sebagai salah satu sarana yang sangat efektif dalam meningkatkan kemampuan dan kualitas pembelajaran. Peserta dapat saling bertukar informasi, gagasan dan pengalaman dan dapat berdiskusi secara langsung dengan tutor. Peserta juga akan memperoleh wawasan keilmuan baru dalam

21 Zakkina Gais dan Ekasatya Aldila Afriansyah, "Analisis Kemampuan Siswa dalam Menyelesaikan Soal High Order Thinking Ditinjau Dari Kemampuan Awal Matematis Siswa", Jurnal "Mosharafa", Volume 6, Nomor 2, (Mei 2017): 255-266

22 Anggit Grahito Wicaksono and Jumanto, "Pengembangan Soal Higher Order Thinking Skills (Hots) Bagi Guru Sekolah Dasar," Adiwidya: Jurnal Pengabdian Masyarakat Universitas Slamet Riyadi 3, no. 2 (2019): 14-20.

23 Tri Isti Hartini and Martin, "Pelatihan Penyusunan Soal High Order Thinking Skill ( HOTS ) Bagi Guru-Guru Fisika Di SMA Di Kota Depok," Indonesia Mengabdi 1, no. 1 (2019): 27-29.

24 Wicaksono and Jumanto, "Pengembangan Soal Higher Order Thinking Skills (Hots) Bagi Guru Sekolah Dasar."

25 Peduk Rintayanti, Siti Istiyati, and Ahmad Syawaludin, "Peningkatan Kemampuan Guru Sekolah Dasar Dalam Merancang Pembelajaran Ilmu Pengetahuan Alam Berkategori Higher Order Thinking Skills (HOTS) Melalui Pelatihan Partisipatif," JPDN: Jurnal Pendidikan Dasar Nusantara 5, no. 2 (2020): 202-210. 
pengembangan kegiatan pembelajaran yang dilakukan di sekolah sebagaimana yang dinyatakan oleh Wicaksono dan Jumanto ${ }^{26}$. Efek lain dari adanya pelatihan adalah dapat meningkatkan pengetahuan dan kemampuan guru dalam menyusun intrumen soal HOTS sebagaimana yang dinyatakan oleh Safi'i dan Amar ${ }^{27}$ dan dapat mengaktifkan guru dalam membuat soal-soal yang berorientasi HOTS28:

Setelah diberikan pelatihan dan tes, rata-rata penguasaan guru dalam menyelesaikan soal HOTS mengalami peningkatan dengan simpangan baku post-tes lebih kecil dibandingkan dengan saat sebelum diberikan perlakukan. Hal ini mengindikasikan varian (sebaran data) lebih memusat di titik pusat dibandingkan saat sebelum diberikan perlakuan. Hasil tersebut sejalan dengan penelitian yang dilakukan oleh Amrah, Nurhaedah, Lutfi, dan Erma Suryani bahwa pendampingan dan pelatihan akan meningkatkan kemampuan menyelesaikan soal HOTS ${ }^{29}$.

Berdasarkan hasil pendampingan, diketahui bahwa untuk merubah kebiasaan dalam pemberian soal dari level C1, C2, dan C3 meningkat menjadi level C4, C5, dan C6 tidaklah mudah. Butuh semangat dan kesabaran serta kerja keras untuk menarasikan soal sederhana menjadi soal dengan level high order thinking. Faktor lain yang mempengaruhi implementasi soal HOTS terhadap pembelajaran guru adalah kondisi siswa yang sangat beragam baik tingkat ekonomi, sosial, daya pemahaman dan minimnya daya saing antar lembaga. Guru merasa kesulitan dalam melayani berbagai kemampuan siswa ${ }^{30}$. Kondisi ini bersesuaian dengan pernyataan Apino dan Retnawati bahwa fakta yang terjadi di lapangan menunjukkan bahwa pembelajaran matematika di Indonesia belum sepenuhnya berorientasi pada higher oreder thinking skills ${ }^{31}$. Tiga faktor utama (guru, siswa, dan lain-lain) ikut berkontribusi terhadap tantangan guru matematika menghadapi penanaman keterampilan berpikir tingkat tinggi ${ }^{32}$. Oleh karenanya perlu ada penekanan lebih besar terhadap kebutuhan mengajar HOTS secara efektif ${ }^{33}$.

Berdasarkan beberapa kendala tersebut, maka peneliti merekomendasikan untuk

26 Wicaksono and Jumanto, "Pengembangan Soal Higher Order Thinking Skills (Hots) Bagi Guru Sekolah Dasar."

27 Imam Safi'i and Faozan Amar, "Pelatihan Penyusunan Instrumen Evaluasi Berstandar HoTS Bagi Guru-Guru SD Di Wilayah Banyudono," Abdimas Dewantara 2, no. 2 (2019): 149.

28 Yunita Sari et al., "Meningkatkan Kemampuan Menyusun Soal IPA Berorientasi HOTS Bagi Guru Sekolah Dasar Gugus Pandanaran Dabin IV UPTD Semarang Tengah," Indonesian Journal of Community Services 1, no. 2 (2019): 175-183.

${ }^{29}$ Amrah, dkk. "Pelatihan Pembuatan soal Berbasis HOTS bagi guru di SD InpresGalangan Kapal IV Kota Makasar", Prosiding Seminar Nasional Lembaga Pengabdian Kepada Masyarakat Universitas Negeri Makassar ISBN: 978-602-555-459-9. 2019. Hal. 527 - 529.

30 Najua Syuhada Ahmad Alhassora, Mohd Salleh Abu, and Abdul Halim Abdullah; "Inculcating Higher-Order Thinking Skills In Mathematics: Why Is It So Hard?"; Man in India; 2017; 51-62

31 Ezi Apino, Heri Retnawati; Developing Mathematical Higher Order Thinking Skills of Senior High School; International Seminar on Mathematics, Science, and Computer Science Education; 2016

32 Najua Syuhada Ahmad Alhassora, Mohd Salleh Abu, and Abdul Halim Abdullah; op.cit; 51-62

${ }^{33}$ Nor'ain Mohd. Tajudin and Mohan Chinnappan, Role Of Higher Order Thinking Skills In Enhancing Mathematical Problem Solving, Man in India, 2017, 209-214 
memberikan pembelajaran dengan melibatkan beberapa strategi pembelajaran, diantaranya adalah dengan menggunakan metode pemecahan masalah Polya, guru bersama dengan siswa melakukan eksplorasi, meminimalisir kegiatan pembelajaran yang dilakukan melalui metode ceramah. Harus ada kolaborasi dan cooperative learning perlu dibiasakan. Beberapa saran yang dikemukakan bersesuaian dengan hasil penelitian Tajudin ${ }^{34}$, bahwa penerapan beberapa model pembelajaran antara lain pembelajaran berbasis proyek (project based learning), pembelajaran dengan pendekatan penyelesaian masalah (problem solving), pembelajaran berbasis masalah (problem based learning), menemukan (discovery/inquiry) menjadi peluang bagi guru untuk mengimplementasikan kegiatan pembelajaran pada level higher oreder thinking skills (HOTS) ${ }^{35}$. Kemampuan seseorang dalam memahami dan menyelesaikan soal-soal yang berbasis HOTS dapat ditingkatkan dengan memberikan bahan ajar yang sesuai ${ }^{36}$. Tidak hanya itu saja, implementasi berupa pemberian soal HOTs perlu diberikan agar proses pembelajaran dapat mendorong siswa mengembangkan kemampuan berfikir kreatif. ${ }^{37}$

Terlepas dari beberapa hambatan yang dihadapi oleh guru, peneliti melihat bahwa ada perkembangan yang sangat signifikan atas perubahan yang dialami guru selama proses pendampingan. Perubahan perilaku ditandai dengan sudah adanya variasi soal yang telah dibuat oleh guru, yang awalnya soal hanya bersifat pemahaman, mengingat dan lebih bersifat rutin menjadi variasi soal yang lebih menantang, bersifat non-rutin. Sudah banyak narasi yang dibuat oleh guru untuk mejadikan soal biasa menjadi soal yang berkualitas high order thinking skills. Selain itu, model pembelajaran juga sudah mengalami perkembangan yang baik, dari pembelajaran yang dilakukan melalui ceramah, top-down menjadi pembelajaran yang lebih kearah cooperative learning, mengingat salah satu tuntutan dari pebelajaran dengan menginternalisasikan high order thinking adalah dengan memberikan suatu problem untuk dipecahkan dan didiskusikan secara bersama-sama.

\section{Kesimpulan}

Pembinaan dan pelatihan guru madrasah dalam rangka peningkatan kompetensi

\footnotetext{
34 Nor'ain Mohd Tajudin; Mathematical Knowledge And Higher Order Thinking Skills For Teaching Algebraic Problem Solving; Proceedings of SOCIOINT15- 2 nd International Conference on Education, Social Sciences and Humanities; 2015

35 Idris Apandi, Pembelajaran dan Penilaian HOTS, Kompasiana, diakses pada tanggal 7 Nopember 2019 melalui laman https://www.kompasiana.com/idrisapandi/58d8e31e8d7a61cc217f38c2/ pembelajaran-dan-penilaian-hots

${ }_{36}$ Musfiqi, S. dan Jailani, "Pengembangan Bahan Ajar Matematika yang Berorientasi pada Karakter dan Higher Order Thinking Skill (HOTS)". PYTHAGORAS: Jurnal Pendidikan Matematika (Juni 2014) 9. No. 1,: 45-59

37 Dhina Cahya Rohim, 'Strategi Penyusunan Soal Berbasis HOTs Pada Pembelajaran Matematika SD', Jurnal BRILIANT: Jurnal Riset Dan Konseptual, 4 November (2019), 436-46 <http://www.jurnal.unublitar.ac.id/ index.php/briliant>.
} 
pedagogik guru matematika melalui penguasaan soal HOTS (Higher Order Thinking Skills) menghasilkan beberapa simpulan antara lain: Kemampuan guru Madrasah dalam menyelesaikan soal-soal high order thinking skills (HOTS) mengalami peningkatan yang signifikan, Implementasi program peningkatakan kemampuan pedagogis guru pada soalsoal HOTS oleh prodi Matematika UIN Sunan Ampel Surabaya dilakukan melalui pemberian workshop/pelatihan dalam merancang dan menyelesaikan soal-soal high order thinking yang selanjutnya diberikan pendampingan. Program tersebut berpengaruh positif terhadap peningkatan kemampuan guru sekaligus implementasinya dalam kegiatan pembelajaran di kelas.

\section{Pengakuan}

Ucapan terimakasih disampaikan kepada semua pihak terutama Subdit Penelitian, Publikasi, dan Pengabdian kepada Masyarakat Direktorat Pendidikan Tinggi Islam Direktorat Jenderal Pendidikan Islam Kementerian Agama RI dalam hal ini, sebagai institusi yang memberikan bantuan dana pengabdian kepada masyarakat. Pengurus PC. LP. Maarif NU Lamongan, Lembaga Penelitian dan Pengabdian kepada Masyarakat (LP2M) UIN Sunan Ampel Surabaya, para dosen Program Studi Matematika Fakultas Saintek UIN Sunan Ampel Surabaya yang telah berkolaborasi dalam melakukan pembinaan dan pendampingan kepada guru-guru di Lamongan.

\section{Daftar Referensi}

Alhassora, Najua Syuhada, Ahmad Mohd Salleh Abu, and Abdul Halim Abdullah; "Inculcating Higher-Order Thinking Skills In Mathematics: Why Is It So Hard?"; Man in India; (2017). 51-62.

Amrah, Nurhaedah, Lutfi, dan Erma Suryani. "Pelatihan Pembuatan soal Berbasis HOTS bagi guru di SD Inpres Galangan Kapal IV Kota Makasar", Prosiding Seminar Nasional Lembaga Pengabdian Kepada Masyarakat Universitas Negeri Makassar. (2019): 527-529. Diakses pada 01 November 2019. https://ojs.unm.ac.id/semnaslpm/article/view/8091

Apandi, Idris. "Pembelajaran dan Penilaian HOTS, Kompasiana", diakses 7 Nopember 2019. https://www.kompasiana.com/idrisapandi/58d8e31e8d7a61cc217f38c2/ pembelajaran-dan-penilaian-hots

Apino, Ezi., Retnawati, Heri. "Developing Mathematical Higher Order Thinking Skills of Senior High School". International Seminar on Mathematics, Science, and Computer Science Education; 2016

Bloom, Benyamin S. "Taksonomy of Educational Objectives (The Clasification of Educational Goals) Handbook 1 Cognitive Domain". London: Longman Group Ltd., 1979.

Budiman, Agus dan Jailani. "Pengembangan Instrumen Asesmen Higher Order Thinking 
Skill (HOTS) Pada Mata Pelajaran Matematika SMP Kelas VIII Semester 1". Jurnal Riset Pendidikan Matematika, Vol. 1 No. 2. 2014.

Chotimah, Chusnul. "Pengembangan Sekolah Berbasis Go Green dan Waste Manajemen untuk Mewujudkan Green School di SDI Miftahul Huda Plosokandang Kabupaten Tulungagung". Engagement: Jurnal Pengabdian Kepada Masyarakat. Vol. 3, No. 2. 2019.

Dian Novianti. "Analisis Kemampuan Berpikir Tingkat Tinggi Siswa Dengan Gaya Belajar Tipe Investigatif Dalam Pemecahan Masalah Matematika Kelas VII Di SMPN 10 Kota Jambi". (April 2014): 1 - 10. Diakses pada 15 November 2019. http://ecampus.fkip.unja.ac.id/eskripsi/data/

pdf/jurnal_mhs/artikel/RRA1C209035.pdf.

Dinni, Husna Nur, "HOTS (High Order Thinking Skills) dan Kaitannya dengan Kemampuan Literasi Matematika". PRISMA 1 Prosiding Seminar Matematika (2018): 170. diakses pada tanggal, 6 Nopember 2019 melalui ttps://journal.unnes.ac.id/sju/index.php/ prisma/

Gais, Zakkina dan Afriansyah, Ekasatya Aldila, "Analisis Kemampuan Siswa dalam Menyelesaikan Soal High Order Thinking Ditinjau Dari Kemampuan Awal Matematis Siswa", Jurnal "Mosharafa”, Volume 6, Nomor 2, (Mei 2017): 255-266.

Hanafi, Mohammad, Nabiela Naily, Nadhir Salahudin, and A. Kemal Riza. CommunityBased Research Sebuah Pengantar. 1st ed. Surabaya: LP2M UIN Sunan Ampel Surabaya, 2015.

Kemdikbud. Konferensi Pers UN 2018 Jenjang SMP. (Online), diakses 1 Oktober 2018. https://kemdikbud.go.id/main/files/do wnload/9c7fdf36a39328d

Muhid, A., Sumarkan, Rakhmawati, Fahmi, L. "Perubahan Perilaku Open Defecation Free (ODF) melalui Program Sanitasi Total Berbasis Masyarakat (STBM) di Desa Babad Kecamatan Kedungadem Kabupaten Bojonegoro". Engagement: Jurnal Pengabdian Kepada Masyarakat, 2(1), (2018), 99-119.

Musfiqi, S. dan Jailani, "Pengembangan Bahan Ajar Matematika yang Berorientasi pada Karakter dan Higher Order Thinking Skill (HOTS)". PYTHAGORAS: Jurnal Pendidikan Matematika (Juni 2014) 9. No. 1,: 45-59.

Martalyna, W., Wardono, dan Kartono. "Integrasi Keterampilan Higher Order Thinking dalam Perspektif Literasi Matematika". PRISMA, Prosiding Seminar Nasional Matematika. Vol 1 (2018): 1, 345-363. diakses pada 03 Desember 2019. https://journal.unnes.ac.id/sju/index.php/prisma/article/view/19616

Nanik Ulfa, Aan Fardani Ubaidillah, \& Isna Nurul Inayati. Pendampingan Guru Melalui Capacity Building dalam Rangka Optimalisasi Implementasi Penilaian Otentik Kurikulum 2013 (K-13) di MINU Curungrejo Kepanjen Malang. Engagement: Jurnal Pengabdian Kepada Masyarakat, 3(1), (2019), 32-43.

Rafiq Badjeber, Jayanti Putri Purwaningrum, "Pengembangan Higher Order Thinking Skills dalam Pembelajaran Matematika di SMP". Guru Tua: Jurnal Pendidikan dan Pembelajaran 1, No. 1, (2018): 36. 
Rintayanti, Peduk, Siti Istiyati, and Ahmad Syawaludin, 'Peningkatan Kemampuan Guru Sekolah Dasar Dalam Merancang Pembelajaran Ilmu Pengetahuan Alam Berkategori Higher Order Thinking Skills (HOTS) Melalui Pelatihan Partisipatif', JPDN: Jurnal Pendidikan Dasar Nusantara, 5.2 (2020), 202-10 <https://ojs.unpkediri.ac.id/index.php/pgsd/article/view/13543/1459>

Rohim, Dhina Cahya, 'Strategi Penyusunan Soal Berbasis HOTs Pada Pembelajaran Matematika SD', Jurnal BRILIANT: Jurnal Riset Dan Konseptual, 4.November (2019), 436-46 <http://www.jurnal.unublitar.ac.id/ index.php/briliant>

Sari, Yunita, Andarini Permata Cahyaningtyas, Mega Mulianing Maharani, Sari Yustiana, and Rida Feronika Kusumadewi, 'Meningkatkan Kemampuan Menyusun Soal IPA Berorientasi HOTS Bagi Guru Sekolah Dasar Gugus Pandanaran Dabin IV UPTD Semarang Tengah', Indonesian Journal of Community Services, 1.2 (2019), 175-83.

Syarifah, Triana Jamilatus, Budi Usodo, Riyadi, "Higher Order Thinking (Hot) Problems To Develop Critical Thinking Ability And Student Self Efficacy In Learning Mathematics Primary Schools", Social, Humanities, and Education Studies (SHEs): Conference Series 1 (2018): 917-925. https://jurnal.uns.ac.id/shes

Safi'i, Imam, and Faozan Amar, 'Pelatihan Penyusunan Instrumen Evaluasi Berstandar HOTS Bagi Guru-Guru SD Di Wilayah Banyudono', Abdimas Dewantara, 2.2 (2019), 149 <https://doi.org/10.30738/ad.v2i2.4176>

Tajudin, Nor'ain Mohd. \& Mohan Chinnappan, "Role of Higher Order Thinking Skills in Enhancing Mathematical Problem Solving", Man in India, 2017, 209-214.

Tajudin, Nor'ain Mohd. "Mathematical Knowledge and Higher Order Thinking Skills for Teaching Algebraic Problem Solving". Proceedings of SOCIOINT15- 2 nd International Conference on Education, Social Sciences and Humanities, 2015.

Hartini, Tri Isti, and Martin, 'Pelatihan Penyusunan Soal High Order Thinking Skill (HOTS) Bagi Guru-Guru Fisika Di SMA Di Kota Depok', Indonesia Mengabdi, 1.1 (2019), 2729.

Thompson. "Mathematics Teachers Interpretation of Higher-Order Thinking in Bloom's Taxonomy". International Electronic Journal of Mathematics Education, Vol. 3, No. 2. (2008). 32.

Widodo dan Kadarwati. "High Order Thinking Berbasis Pemecahan Masalah Untuk Meningkatkan Hasil Belajar Berorientasi Pembentukan Karakter Siswa”. Cakrawala Pendidikan. Vol. 3 No. 1. (2013), 161-171.

Wicaksono, Anggit Grahito, and Jumanto, 'Pengembangan Soal Higher Order Thinking Skills (Hots) Bagi Guru Sekolah Dasar', Adiwidya: Jurnal Pengabdian Masyarakat Universitas Slamet Riyadi, 3.2 (2019), 14-20. 